\title{
SURFACE ENERGEY, $\mathrm{CO}_{2}$ FLUXES AND SEA ICE
}

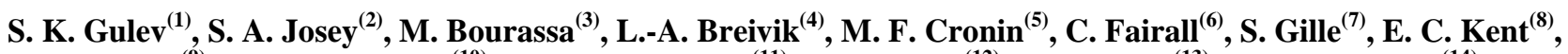 \\ C. M. Lee ${ }^{(9)}$, M. J. McPhaden ${ }^{(10)}$, P. M. S. Monteiro ${ }^{(11)}$, U. Schuster ${ }^{(12)}$, S. R. Smith ${ }^{(13)}$, K.E. Trenberth ${ }^{(14)}$, D. \\ Wallace $^{(15)}$, S.D. Woodruff ${ }^{(16)}$ \\ ${ }^{(1)}$ Institute of Oceanology, Russian Academy of Sciences (IORAS), Moscow, Email: gul@sail.msk.ru \\ ${ }^{(2)}$ National Oceanography Centre (NOC), Southampton, UK, Email: simon.a.josey@noc.ac.uk \\ ${ }^{(3)}$ Florida State University (FSU), Tallahassee, FL, USA, Email: bourassa@ coaps.fsu.edu \\ ${ }^{(4)}$ Norwegian Meteorological Institute, Norway, Email: l.a.breivik@met.no \\ ${ }^{(5)}$ National Oceanic and Atmospheric Administration Pacific Marine Environmental Laboratory (NOAA PMEL), \\ Seattle,WA, USA, Email: Meghan.F.Cronin@noaa.gov \\ (6) National Oceanic and Atmospheric Administration/Earth System Research Lab/Physical Science Division \\ (NOAA/ESRL/PSD), Boulder, CO, USA, Email: Chris.Fairall@noaa.gov \\ (7) University of California San Diego, Scripps Institution of Oceanography (UCSD, SIO), La Jolla, CA, USA, Email: \\ sgille@ucsd.edu \\ ${ }^{(8)}$ National Oceanography Centre (NOC), Southampton, UK, E-mail: eck@noc.ac.uk \\ ${ }^{(9)}$ Applied Physics Laboratory (APL), University of Washington, Seattle, WA, Email: craig@apl.washington.edu \\ ${ }^{(10)}$ National Oceanic and Atmospheric Administration Pacific Marine Environmental Laboratory (NOAA PMEL), \\ Seattle,WA, USA, Email: michael.j.mcphaden@noaa.gov \\ ${ }^{(11)}$ Council for Scientific and Industrial Research (CSIR), South Africa, Email: pmonteir@csir.co.za \\ ${ }^{(12)}$ Ute Schuster, University of East Anglia (UEA),Norwich, Email: U.Schuster@uea.ac.uk \\ ${ }^{(13)}$ Center for Ocean-Atmospheric Prediction Studies ( COAPS), FSU, Tallahassee, FL, USA, \\ Email:smith@coaps.fsu.edu \\ (14) National Center for Atmospheric Research (NCAR), Boulder, CO, USA, Email: trenbert@ucar.edu \\ ${ }^{(15)}$ Duglas Wallace, Leibniz Institute of Marine Sciences (IFM-GEOMAR), Kiel, Germany, Email: dwallace@ifm- \\ geomar.de \\ ${ }^{(16)}$ National Oceanic and Atmospheric Administration Earth System Research Lab (NOAA ESRL), Boulder, CO, USA, \\ Email: Scott.D.Woodruff@noaa.gov
}

\begin{abstract}
This paper reviews the current state of observation, parameterization and evaluation of surface air-sea energy and gas fluxes, and sea ice, for the purposes of monitoring and predicting the state of the global ocean. The last 10 years have been marked by the development of more accurate parameterizations of turbulent fluxes, in particular COARE-3 (Coupled Ocean-Atmosphere Response Experiment). A seamless approach to surface flux observing systems is also being developed ranging from highly accurate observations on buoys and research ship campaigns to the longstanding Voluntary Observing Ship (VOS) scheme. In addition to flux products based on in situ data, satellite measurements and numerical weather prediction, several hybrid products have been developed which combine data from these different sources. Satellite monitoring of sea ice has been extended to more accurate and higher resolution estimation of ice extent and quantification of ice thickness. Global air-sea $\mathrm{CO}_{2}$ flux products are now based on significantly better-sampled datasets reducing the uncertainty in the ocean carbon budget. Despite these advances, considerable gaps remain in our understanding of air-sea fluxes, for example, at both high and low wind speeds, for gas and aerosol exchange and in marginal ice zones. Furthermore, there are
\end{abstract}

serious concerns about the recent decline in the number of VOS observations. Closure of global and regional energy balances still cannot be achieved without adjustments to the flux fields and/or the underlying surface meteorological variables. The impact of sampling on interannual variability of fluxes makes estimates of climate tendencies in air-sea exchanges highly uncertain. In order to meet these challenges we formulate a future vision of a surface flux observing system, which provides a synergy of in situ measurements (buoys, research vessels and merchant ships), remote sensing and models.

\section{INTRODUCTION}

Air-sea fluxes play a key role in the global climate system, coupling the ocean and atmosphere. The exchanges of heat and freshwater together form the density flux, which drives ventilation of the thermocline and surface water mass transformation. The surface wind stress affects the ocean circulation and determines the dynamics of wind waves. Surface heat fluxes and evaporation provide diabatic heating for the lower atmosphere, influencing atmospheric dynamics, including extratropical and tropical cyclones. Changes in sea ice extent and thickness release anomalous amounts of fresh water to the ocean; and also change the 
area of ice-free water, thereby significantly altering the exchange of heat, freshwater and gases.

Fundamentally, surface fluxes involve an exchange of something from one phase to another, and so what is lost from the atmosphere must be gained by the ocean, or vice versa. Accordingly, viewing the oceanatmosphere system as a whole and as a coupled system means that surface fluxes should relate to conservation and budgets of mass, heat, energy, momentum, chemical species, etc. and the fluxes should not be viewed in isolation.

OceanObs'99 [1] suggested the deployment of flux reference buoys, upgrading the Voluntary Observing Ship (VOS) scheme by equipping VOS with improved sensors and extension of metadata, and development of packages for routine direct turbulent flux measurements on a wide range of ships. Furthermore, [2] identified large biases in different flux products and suggested strategies for intercomparison and validation activities, as well as the development of a new generation of global flux products incorporating in situ, NWP (Numerical Weather Prediction) and satellite data through optimal blending.

During the decade since OceanObs'99, some of this vision has been implemented, particularly in different modules of the Global Ocean Observing System (GOOS). Significant progress has been achieved in the development of parameterizations, methods of surface flux validation, determining the magnitudes of flux uncertainties and generation of new global flux products for different applications. These achievements have established a new level of quantitative surface flux estimation. At the same time, many unresolved problems have been identified, and the uncertainties in many surface flux components are still too large to meet the requirements of ocean monitoring and prediction.

This paper provides an overview of the achievements of the last decade in observing, parameterizing and understanding the mechanisms of surface fluxes. Furthermore, we describe achievements in the development of global and regional surface flux products for climate studies and ocean modelling. Finally, we discuss the requirements for surface flux estimates over the next decade and develop recommendations for future flux observing systems.

\section{ACCURACY, RESOLUTION AND PARAMETERIZATIONS OF AIR-SEA ENERGY FLUXES}

\subsection{Required accuracy}

A target net surface heat flux accuracy of $10 \mathrm{~W} / \mathrm{m}^{2}$ at monthly to seasonal time scales [3] implies a required accuracy of $2-3 \mathrm{~W} / \mathrm{m}^{2}$ for individual surface flux components [4] which is still very difficult to achieve. Furthermore, there is no unique value for the accuracy needed with resolution (both spatial and temporal) requirements also being a key issue. Figure 1 shows schematically the spatial and temporal scales associated with different oceanic and atmospheric processes, along with the accuracies required for the adequate description of surface fluxes relevant to those processes. Accuracy requirements are spread from $0.1 \mathrm{~W} / \mathrm{m}^{2}$ to $20-50 \mathrm{~W} / \mathrm{m}^{2}$ with decreasing spatial and temporal scales.

Surface turbulent fluxes in Western Boundary Current regions on timescales from hours to days locally amount to more than $1000 \mathrm{~W} / \mathrm{m}^{2}$, which is an order of magnitude larger than mean monthly and seasonal values. Variations of surface net heat flux during several weeks of the Indian monsoon break cycle may be as large as $100-200 \mathrm{~W} / \mathrm{m}^{2}$. An annual change in the latent heat flux by $1 \mathrm{~W} / \mathrm{m}^{2}$ is equivalent to an annual $12 \mathrm{~mm}$ change in water column depth. The observed 50-year changes in the upper $700 \mathrm{~m}$ ocean heat content reported by IPCC AR4 (Intergovernmental Panel on Climate Change, Fourth Assessment Report) [5] may be regionally equivalent to a net heat flux signal of 4-5 $\mathrm{W} / \mathrm{m}^{2}$. Typically, flux datasets show changes that are larger than these observed signals.

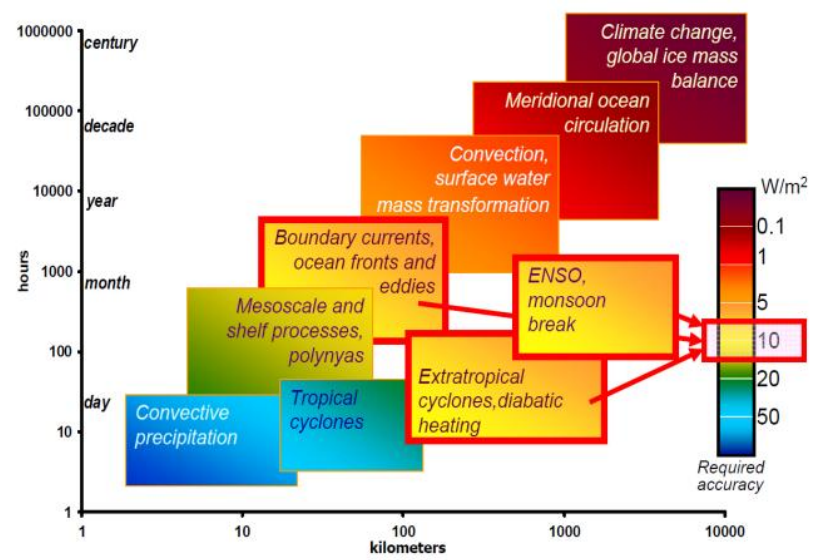

Figure 1. Schematic representation of different oceanic and atmospheric processes as a function of their spatial and temporal scales along with the accuracy required for the adequate description of surface fluxes relevant to these processes (given in color). Red boxes tentatively correspond to the processes requiring accuracy of 10 $W / m^{2}$.

Accuracy requirements for the freshwater flux (Evaporation - Precipitation, E-P) are more difficult to estimate compared to the heat fluxes. Existing estimates of the freshwater contribution to surface water mass transformation [6, 7 and 8] imply from 30 to $150 \mathrm{~mm}$ 
year $^{-1}$ E-P over mid and subpolar latitudes consistent with [9].

Global model grid spacing of $1 / 8^{\circ}$ to $1 / 12^{\circ}$ are becoming widely used, requiring forcing at $5-10 \mathrm{~km}$ spatial scales and 30-60 minute temporal scales. These requirements are far from being met by reanalysis and by most operational products [10]. For instance, available flux products produce insufficient ocean mixing due to poor representation of diurnal variations and small scale variability such as at atmospheric fronts. Ocean wind wave modelling requires highly accurate wind vectors with high space-time resolution and adequate representation of a geostrophic patterns [11].

The dependence of accuracy and resolution requirements on scientific targets, applications and time scales implies that it is hard to expect the development of any flux product, which will meet all requirements and will be universally applicable across scales and scientific objectives.

\subsection{Development of parameterizations}

Considerable progress in the development of surface air-sea flux parameterizations and in-situ observations became possible as a result of the development of autonomous flux systems, such as AutoFlux. Proposed initially by [1] these non-campaign observation programs [12 and 13] considerably enlarge data sets of direct flux measurements under different conditions and will facilitate further improvement of flux parameterizations, particularly at high wind speeds.

The COARE-3 (Coupled Ocean-Atmosphere Response Experiment) algorithm [14] represents a major development in the parameterisation of surface fluxes based on a large dataset of direct flux measurements. COARE-3 is applicable for the wind speed range from 0 to $20 \mathrm{~ms}^{-1}$ and provides a flux estimation accuracy of $5 \%$ for $0-10 \mathrm{~ms}^{-1}$ and $10 \%$ for $10-20 \mathrm{~ms}^{-1}$. An extension of COARE-2.5 algorithm [15] accounts for sea spray impact on turbulent fluxes under winds higher than 10 $\mathrm{ms}^{-1}$, when spray-mediated heat transfer becomes increasingly important.

Existing parameterizations of turbulent fluxes result in potentially large differences in flux estimates (Fig. 1, [4]). The turbulent transfer coefficients vary with wind speed and atmospheric stability and have other less well understood dependencies on sea state, wave breaking and white-capping, wind history, sea surface temperature, surfactants and rain. Nevertheless, the present spread of the transfer coefficients is much smaller compared to that which was 10-20 years ago and, importantly we have now good reference data set to rely on (Fig. 2).
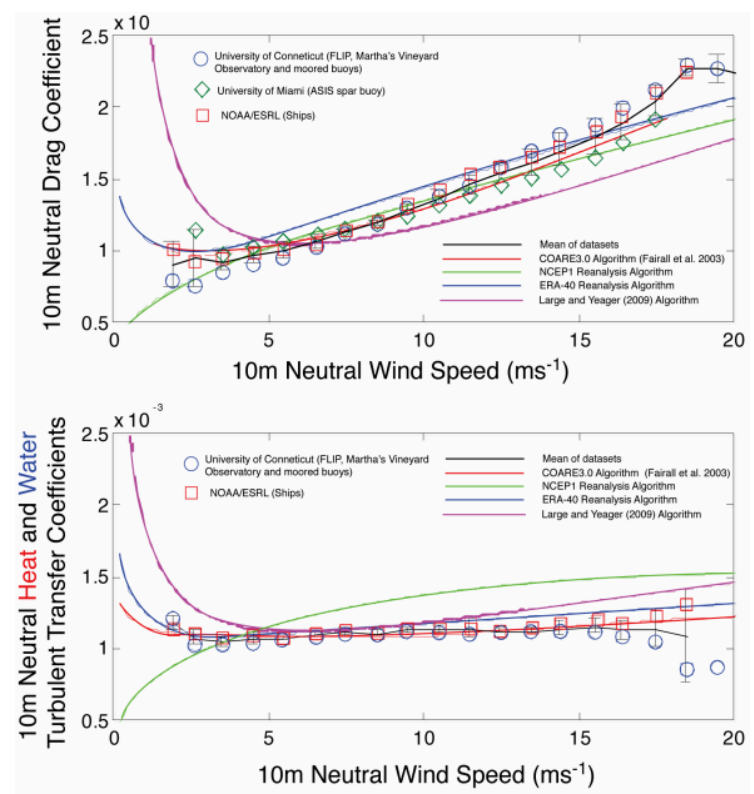

Figure 2: Flux transfer coefficients as a function of $10 \mathrm{~m}$ neutral wind speed. Top: drag coefficient (momentum); Lower: transfer coefficient from observations for heat (red squares) and water (blue circles), heat and water transfer coefficients are the same for those parameterizations shown.

Underway measurements of shortwave and longwave radiation at sea have become available from a number of activities, such as the Shipboard Automated Meteorological and Oceanographic System (SAMOS) initiative ([16]; http://samos.coaps.fsu.edu). Another source of radiative measurements is provided by buoy observing systems (PIRATA (Prediction and Research Moored Array in the Atlantic), TAO/TRITON (Tropical Atmosphere Ocean/Triangle Trans-Ocean Buoy Network) and RAMA (Moored Array for AfricanAsian-Australian Monsoon Analysis and Prediction)) [17 and 18]. Underway measurements provide the basis for the improvement of shortwave and longwave [19] radiation parameterizations, and are also used for the validation of satellite radiative fluxes [20].

The legacy of SHEBA (Surface Heat Budget of the Arctic Ocean) allowed for the improvement of the existing and development of new parameterizations of fluxes over sea ice [21]. The SHEBA site is now open water during summer, and the ice conditions that SHEBA sampled most thoroughly are predicted to cease to exist in coming decades. Flux measurements during the last decade, including IPY (International Polar Year) campaigns, provided considerable growth of the flux databases over sea ice. The recent advances in parameterization of surface fluxes over ice and in the presence of ice are discussed briefly by [22]. 


\section{MEASUREMENTS OF SURFACE ENERGY FLUXES AND RELATED VARIABLES}

Progress in measuring in-situ fluxes has been associated with the development and standardization of observational techniques for research quality meteorological observations. A detailed overview of sensors [23] includes those for gas and aerosol fluxes. A comprehensive guide [24] helps researchers make accurate flux and meteorological measurements at sea. The primary source for widespread measurements of marine meteorological variables is not direct measurements, but the VOS programme [25 and 26] and within the tropical band, the array of surface moorings [17]. Research vessels and buoys provide limited subsets of research quality high-resolution data. In contrast, the VOS scheme provides lower accuracy but more widespread measurements of a limited number of parameters (Fig. 3).

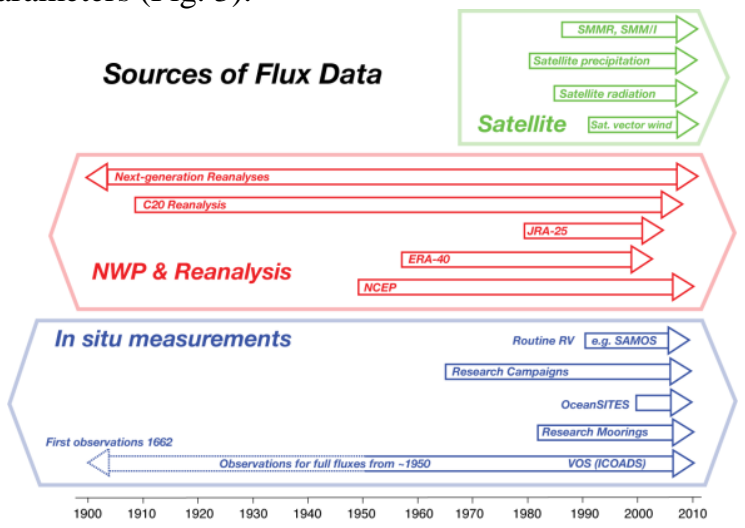

Figure 3: Timeline showing availability of surface flux and flux-related data.

\subsection{Buoys}

Oceanobs'99 [1] proposed a total of 22 Flux Reference Sites should be maintained over the global ocean. During the last decade, this idea has to some extent been realized through a subset of buoys in the global (OCEAN Sustained Interdisciplinary Time series Environment observation System) array [27], which are equipped with sensors providing high quality surface meteorological, precipitation and radiative flux measurements, thus closing the surface energy and freshwater budgets. The arrangement of the present and planned near-term OceanSITES flux reference sites corresponds in part to the scheme proposed by [1 and 27].

The tropical network of moored buoys consists of three regional components (PIRATA, TAO/TRITON and RAMA) [17]. These buoys carry basic meteorological sensors to support determination of the air-sea fluxes of heat, freshwater, and momentum via the bulk formulae; many are enhanced with barometric pressure, rain, and solar flux sensors. Five of the TAO/TRITON network buoys and four of each PIRATA and RAMA networks buoys have now been upgraded to meet the requirements of a full Flux Reference Site with some measuring $\mathrm{pCO}_{2}$ (partial pressure of carbon dioxide) [28]. The combined network is irregularly spatially distributed within the relatively well-sampled tropical oceans but severely under-samples the mid and high latitudes, precluding the accurate estimation of the Southern Ocean surface buoyancy budget [22].

In ice-covered regions the Ice-Based Observatories (IBOs) provide basic meteorological and flux measurements. In recent years, the improvement of packages has expanded the range of boundary layer measurements. Examples include the JAMSTECH/METOCEAN M-CAD (Japan Agency for Marine-Earth Science and Technology/METOCEAN Compact Arctic Drifter), which adds wind velocity and upper ocean temperature and salinity, the Cold Regions Research and Engineering Laboratory (CRREL) Ice Mass Balance Buoy, which measures the position of the top and bottom of the ice, along with high-resolution temperature measurements that extend across the atmosphere-ice-ocean interface and the U.S. Naval Postgraduate School Autonomous Ocean Flux Buoy (AOFB) [29]. Although the drifting sea ice provides a useful platform, difficult operating conditions and extremely limited access hampers the community's ability to collect detailed meteorological measurements across the ice-covered Arctic.

\subsection{Research ships}

Since OceanObs'99, there have been considerable advances in the management of underway research quality meteorological and flux observations collected by research vessels [16]. The SAMOS initiative, starting in 2003, collates high-resolution meteorological measurements from as many as 20 US RVs (United States Research Vessels) operating in the Atlantic and Pacific and the Australian Integrated Marine Observing System (IMOS; http://www.imos.org.au) is a regional initiative around Australia. Some limitations are associated with the effects of ship heating and airflow distortion [30, 31 and 32], but which careful sensor sitting and redundant instrumentation can partially overcome [24].

\subsection{Voluntary Observing Ships (VOS)}

The VOS data extend in limited areas back to the $17^{\text {th }}$ $18^{\text {th }}$ centuries (Fig 3) [15 and 26], with instrumental observations largely beginning in the mid- $19^{\text {th }}$ century. Most of the VOS data (together with marine data from many operational buoys and some other in situ platforms for recent decades) are included in the regularly updated International Comprehensive OceanAtmosphere Data Set (ICOADS, [33]). Traditional VOS 
provide in situ measurements of SST (Sea Surface Temperature), air temperature, humidity, sea level pressure (SLP), surface winds (either measured or visually estimated) and cloud cover - along with cloud types, present and past weather, and wind and swell wave characteristics (all of which are visually estimated).

Random and systematic uncertainties of VOS observations are typically larger than those for research quality observations and arise from inaccuracy of sensors and their poor exposure [34]. Correction of the biases often requires metadata, which is not always available or accurate. Changing observational practices, as well as the size and superstructure of ships, give rise to time-dependent biases. During the last two decades the number of VOS reports has continuously declined and the number of reports per year post-2000 is less than half that in the 1960s-1980s. Widespread installation of Automated Weather System (AWS) packages on some national VOS fleets has drastically reduced the number of visual reports of cloudiness, waves and weather conditions during recent years.

Since OceanObs'99, considerable progress has been achieved in minimization of biases in the VOS data [35]. Observational metadata is now digitally available [25 and 36] and selected metadata for 1966-2007 are now an integral part of ICOADS (International Comprehensive Ocean-Atmosphere Data Set ) [33]. The VOS Climate Project (VOSClim) targeted a subset of higher quality VOS observations seeking further improvements in data accuracy, and potentially for implementing better observational practices. The VOSClim practices are being extended more widely, and include additional parameters and co-located NWP model output, which will aid the understanding and correction of data bias.

\section{SURFACE ENERGY FLUX PRODUCTS AND THEIR UNCERTAINTIES}

\subsection{VOS-based Surface Flux Climatologies}

OceanObs'99 was marked by the appearance of the NOC1.1 climatology (National Oceanography Centre surface flux climatology) [37] in which, for the first time, observational metadata was employed to correct individual observations where possible. The major problem with this product was a strong imbalance of the net surface flux over the global ocean with a negative bias (i.e. underestimation of the ocean heat loss) of about $30 \mathrm{~W} / \mathrm{m}^{2}$, resulting in unrealistic estimates of the ocean Meridional Heat Transport (MHT) in many areas. The primary factors responsible for this imbalance were thought to include biases arising from undersampling, parameterization uncertainties and undetermined biases in the basic variables.

To minimize these imbalances it is possible to apply the linear inverse discrete theory for the adjustment of individual variables and parameterization coefficients within a reasonably chosen range [38]. This approach was applied to the NOC1.1 climatology, using a wide range of new MHT estimates from WOCE (WorId Ocean Circulation Experiment) [39]. The resulting product (termed NOC1.1a) achieved closure of the global budget to within $2 \mathrm{~W} / \mathrm{m}^{2}$. The implied MHT from a range of surface flux products is shown in Fig. 4. However, this approach has its own problems as the adjusted fluxes no longer showed agreement with research buoy measurements in the subduction region of the North-East Atlantic, indicating that the adjustments were too strong, at least in this region.

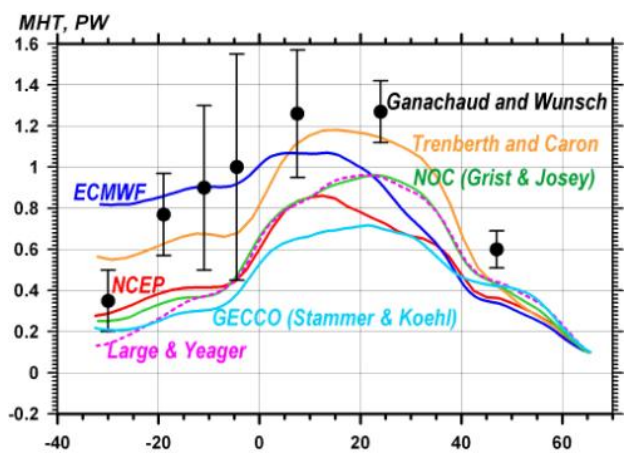

Figure 4. Atlantic MHT estimates from different surface flux datasets.

There were extensive efforts to estimate the different sources of uncertainties in VOS-based fluxes and flux related variables [40]. Large random uncertainties for most variables (more than $1{ }^{\circ} \mathrm{C}$ for SST and air temperature and more than $2 \mathrm{~ms}^{-1}$ for scalar wind speed) were demonstrated [35 and 41]. Sampling errors in individual variables and fluxes [35, 42 and 43] may amount to $60-80 \mathrm{~W} / \mathrm{m}^{2}$ in the net flux in the poorly sampled Southern Ocean and subpolar North Atlantic.

A new version of the NOC climatology [44 and 45], termed NOC2.0, provides error estimates for all of the basic meteorological and derived flux fields, using optimal interpolation of daily estimates of ICOADS Release 2.4 ship data and spans the period 1973-2006. It is presented as a time series of monthly mean values on a 1-area grid and the standard deviation of daily values is also available.

Despite the well-known limitations of VOS-based flux products, their development remains an important challenge, as VOS provide the only source of multidecadal marine meteorological data. Furthermore, these products are the basis for comparative assessments 
of alternative flux products from remotely sensed data, reanalyses and "residual" methods.

\subsection{Remotely Sensed Surface Fluxes}

\subsubsection{Remotely sensed turbulent fluxes and related variables}

At present, satellite SST effectively contributes to operational products, reanalyses and objective analyses. Scatterometers, passive polarimetric sensors (WindSat) and Synthetic Aperture Radar now provide a variety of estimates of vector winds [46]. Accurate scalar winds with moderate spatial resolution are available from passive microwave radiometers from SSM/I (Special Sensor Microwave/Imager). Combination of several satellites (SSM/I, QuikSCAT (Quick Scatterometer Satellite), TMI (TRMM (Tropical Rainfall Measuring Mission) Microwave Imager), AMSR (Advanced Microwave Scanning Radiometer)) allowed for the provision of a blended 0.25 degree grid spaced global satellite wind product covering the period from 1987 onwards [47]. The accuracy (one standard deviation) of QuikSCAT and AMSR winds is roughly $0.6 \mathrm{~ms}^{-1}$ or better. However, there are considerable biases between instruments for high wind speeds due to differences in spatial sampling and averaging.

Production of satellite based turbulent heat flux products requires application of bulk formulae to remotely sensed parameters. These include retrievals of air temperature which is still highly problematic. In recent years some progress has been achieved by the multichannel analysis of several satellites resulting in RMS differences of less than $1 \mathrm{~g} / \mathrm{kg}$ for humidity and less than $2^{\circ} \mathrm{C}$ for temperature [48].

The Hamburg Ocean-Atmosphere Parameters and Fluxes from Satellite Data (HOAPS), based on SSM/I data, provides turbulent fluxes and net long-wave radiation and precipitation. The latest HOAPS-3 update ([49], http://www.hoaps.zmaw.de/) covers the period from 1987 onwards with monthly data at $0.5^{\circ}$ grid spacing and half-daily data at $1^{\circ}$ spacing. The Japanese J-OFURO (Ocean Flux data sets with Use of Remote sensing Observations) ([50],) http://dtsv.scc.utokai.ac.jp/j-ofuro/ product provides 1-degree daily and monthly fluxes with $0.25^{\circ} \times 0.25^{\circ}$ grid spacing version available from 2002. Daily and monthly products of latent heat fluxes at $1^{\circ}$ grid spacing are provided by the Goddard Satellite-Based surface Turbulent Fluxes (GSSTF) Data ([51], http://disc.sci.gsfc.nasa.gov/precipitation/dataholdings/access/gsstf2.0.shtml). The IFREMER (French Research Institute for Exploitation of the Sea) flux product [52] makes use of scatterometer winds, in addition to SSM/I data, and covers the period from 1992 onwards. A further turbulent flux product with $0.3^{\circ}$ grid spacing was developed using improved treatment of the relationship between latent heat flux and brightness temperature [53]. At present, validation and intercomparison efforts [51 and 54] do not allow for unconditional discrimination of these products and demonstrate regional differences between e.g. latent heat flux estimates from a few to several tens $\mathrm{W} / \mathrm{m}^{2}$.

\subsubsection{Radiative fluxes}

Satellite based estimates of surface radiative fluxes use measurements of top-of-the-atmosphere radiation with radiative transfer models to estimate the surface flux. Data are available from both polar orbiting (e.g. Advanced Very High Resolution Radiometer (AVHRR) and TIROS (Television Infra-Red Observation Satellite) Operational Vertical Sounder (TOVS) on NOAA (National Oceanic and Atmospheric Administration) satellites and the NASA (National Aeronautics and Space Administration) Moderate Resolution Imaging Spectroradiometer (MODIS)) and Geostationary Operational Environmental Satellites (GOES).

The International Satellite Cloud Climatology Project (ISCCP, [55]) provides solar and IR (infrared) radiative surface fluxes for 1983-2006 from GOES satellites. Climatological net SW (shortwave) radiation from ISCCP is compared in [10] with reanalyses climatologies. Quality declines near the poles and in stratocumulus regions [56]. MODIS-derived satellite radiative fluxes from the CERES (Clouds and the Earth's Radiant Energy System) program [20 and 57] offer potential advantages in accuracy, but have poorer sampling and could potentially be used to improve ISCCP products, particularly at high latitudes since 1998. However, when surface fluxes are evaluated in a holistic framework [58], large errors of tens $\mathrm{W} \mathrm{m}^{-2}$ are evident in radiative fluxes from ISCCP and CERES, and were ascribed mainly to the downward longwave.

\subsubsection{Precipitation}

Precipitation is very difficult to sample because of its patchiness and intermittency, and only remote sensing methods offer any spatial coverage at short time scales. Satellite-based precipitation products include the Climate Prediction Center Merged Analysis of Precipitation (CMAP) product [59], the Global Precipitation Climatology Project (GPCP, [60]) and CPC Morphing Technique (CMORPH, [61]). Regional differences between different satellite precipitation products may amount to $15-25 \%$ in different oceanic regions with even higher spread for individual months [62]. Now observations from CLOUDSAT provide new insights into precipitation and the errors in sensors [63]. 
The Precipitation Radar on the Tropical Rainfall Measuring Mission (TRMM) offers the most accurate precipitation estimates [64], but its coverage is limited to the tropics and the period since December 1997 with sampling errors being significant [65]. Temporal sampling is a major issue for space-based measurements, which measure only rates at time of observation. Converting those to accumulated amounts is not a solved problem.

\subsection{Surface Fluxes from Atmospheric Reanalyses and Operational Analyses}

A comprehensive review of the reanalysis potential for understanding the ocean's role in climate system is presented in [10]. Atmospheric reanalyses [66, 67, 68 and 69] have been produced by the major meteorological centers (NCEP, ECMWF and JMA (National Centers for Environmental Prediction, European Centre for Medium-Range Weather Forecasts and Japan Meteorological Agency)). They cover various periods, from 1948 (NCEP-1 (), from 1979 NCEP/DOE (National Centers for Environmental Prediction/Department of Energy), from 1958-2002 ERA-40 (ECMWF (European Centre for MediumRange Weather Forecasts) A Forty-Year European ReAnalysis), from 1979 JRA (Japan reanalysis), from 1989 (ERA-Interim). The spectral resolution of reanalysis models varies from T62 in NCEP to T159 in ERA-40, although newer reanalyses underway are at higher resolution (T255 for ERA-interim, T319 for JRA-55, T382 for CFSRR (CFS (Climate Forecast System) Reanalysis and Reforecasts), and $0.5^{\circ}$ for NASA MERRA (National Aeronautics and Space Administration Modern Era Retrospective-analysis for Research and Applications)). From the output archives surface fluxes are available at $1^{\circ}$ to $2.5^{\circ}$ grid spacing and hourly to 6-hour temporal spacing.

A tropical negative bias in short wave radiation with respect to ISCCP-FD datasets (http://isccp.giss.nasa.gov/projects/flux.html) is evident in both NCEP-1 and NCEP/DOE reanalyses resulting in considerable underestimation (up to $40-60 \mathrm{~W} / \mathrm{m}^{2}$ ) of the tropical net flux [10]. Precipitation in reanalyses, especially over tropics and mid-latitudes suffers from the strong impact of the spin-up on precipitation that was one of the critical problems of ERA-15. In the ERA-40 and ERA-Interim reanalyses, the spin-up effect on the convective precipitation was considerably reduced in comparison to ERA15 [10 and 69] and representation of the oceanic water cycle (e.g., evaporation minus precipitation) in NCEP/DOE reanalysis was considerably improved compared to NCEP-1 [70] due to the updated precipitation parameterizations and more realistic cloud-top cooling [67]. Precipitation from atmospheric reanalyses can show unrealistic trends (ERA-40), or incorrect seasonal cycles [71] although reanalyses better than satellite products reproduce interannual changes associated with the North Atlantic Oscillation and ENSO (El Niño Southern Oscillation) [72].

During the past decade there have been many regional evaluations of reanalyses surface fluxes against in-situ observations. Overestimation of NCEP-1 turbulent sensible and latent fluxes of up to $20-40 \mathrm{~W} / \mathrm{m}^{2}$ in winter occurs in the western boundary current regions (Gulf Stream and Kuroshio) and in the Labrador Sea [50 and 73]. Heat loss in both NCEP-1 and ECMWF reanalyses is overestimated versus the WHOI (Woods Hole Oceanographic Institute) subduction buoy array in the Eastern North Atlantic [74]. In contrast, in the Agulhas region there was demonstrated significant underestimation of sensible and latent heat fluxes in reanalyses [75]. Thus, high quality in situ flux data are required for validation: the WCRP (World Climate Research Program) Surface Flux Analysis (SURFA) initiative provides an infrastructure for comparisons.

\subsection{Hybrid Surface Flux Products}

The approach, which combines data from satellites and reanalyses in an attempt to produce a more accurate final product [76, 77, and 78] results in products referred to as hybrid flux datasets (also sometimes called blended fields).

The OAFlux (Objectively Analyzed air-sea Fluxes) product [77] has been produced by combining several reanalysis (NCEP1, NCEP/DOE, ERA-40) and satellite data sets using a variational approach [79]. The COARE-3 (Coupled Ocean-Atmosphere Response Experiment) bulk algorithm was then applied to generate $1^{\circ}$ daily sensible and latent heat flux fields from 1985 and monthly fields from 1958, although the data input for blending before 1985 consisted only of reanalysis variables. Subsequently, over 100 buoys were used for further evaluation of the product, which revealed good agreement with the in situ data [80]. Figure 5 shows the global surface net heat flux from the OAFlux product.

The Large and Yeager [78] hybrid flux data set has gone through several versions and is confusingly often referred to as the CORE (Common Ocean Reference Experiment) fluxes. In [78] the authors take individual variables from NCEP1 reanalysis and implement plausible adjustments to the winds (using satellite data from QSCAT), and to surface humidity (taking as a reference the NOC1.1 climatology). Sensible and latent heat fluxes, as well as wind stress, were computed using bulk formulae suggested by [81]. These fluxes were combined with ISCCP-FD radiation data and the 
resulting net heat flux exhibits closure of the global heat balance and realistic estimates of MHT (Fig. 4).

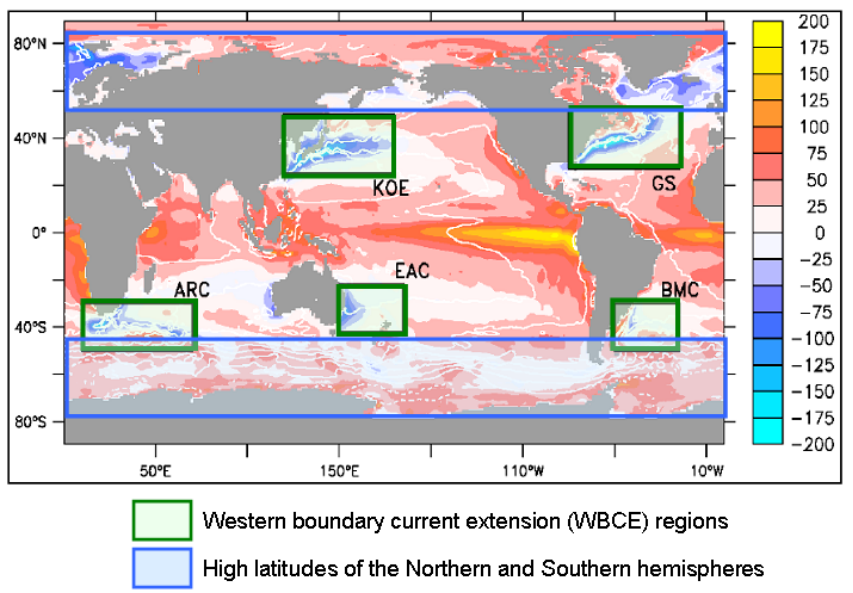

Figure 5. Regional focus of the air-sea flux studies for the next decade. Climatological mean net surface heat flux into the ocean from the OAFLUX (Yu and Weller, 2007). White contours indicate mean dynamic sea level (Rio, 2004). Green rectangles indicate WBCE regions: Gulf Stream (GS), Kuroshio (KOE), Agulhas Retroflection Current (ARC), East Australian Current system (EAC) and the Brazil-Malvinas Confluence (BMC).

Development of forcing functions for ocean model experiments is conceptually close to the strategy of the development of hybrid surface flux products, and the CORE fluxes were developed to provide a reference atmospheric forcing function for numerical experimentation with OGCMs (Oceanic General Circulation Models) initiated by the CLIVAR Working Group on Ocean Model Development [82]. Roeske [83] designed another dataset to force ocean models of the OMIP (Ocean Model Intercomparison Project) using the ERA15 (ECMWF Re-Analysis (for 15 years)) fields. To produce a climatological year of fluxes for 1979-1993 he applied adjustments to close heat and freshwater budgets by means of an inverse procedure. Several surface flux data sets for forcing GCMs (Global Climate Models) have also been produced under the DRAKKAR project (multi-scale ocean modelling project) [84]. These so-called DRAKKAR Forcing Sets (DFSs) [85] use adjusted variables from ERA-40, modified precipitation and also account for the model impact on SST.

\subsection{Residual estimates of surface fluxes from atmospheric and oceanic reanalyses}

Residual methods also provide useful net surface heat and freshwater flux estimates with particular benefits in regions poorly sampled by in situ observations. Surface fluxes may be deduced independently from surface flux parameterizations as residuals from top of the atmosphere net radiative flux satellite observations and atmospheric model reanalysis flux divergences [58 and 86]. The latter deduced ocean heat flux divergences and transports as a function of time of year, for instance. It is also possible to diagnose surface heat fluxes from closure of the upper ocean heat balance [87 and 88] and the advent of the Argo (Array for Real-time Geostrophic Oceanography) profiling float array has the potential to lead to major advances in this area in the near future.

Ocean state estimation offers a further means to potentially refine surface fluxes in order to make them more consistent with ocean observations [89, 90, 91 and 92]. Assimilation of ocean data adds mesoscale structure to the fluxes that is not present in the original flux forcing fields [93]. The residual method inherently builds in budget aspects by requiring the surface flux to match the loss or gain in the quantity from the atmosphere or ocean [58]. When this is done in a coupled framework, it potentially provides a powerful constraint and complementary approach to direct flux estimates.

\section{SURFACE FLUXES OF $\mathrm{CO}_{2}$ : MEASUREMENTS AND GLOBAL PRODUCTS}

\subsection{Accuracy requirements, in-situ measurements and parameterizations}

Biases in monthly fields of oceanic $\mathrm{pCO}_{2}$ remain a significant factor of uncertainty at both regional and global scale [94]. For some regions, even the sign of climatological $\mathrm{CO}_{2}$ flux is questionable. This highlights the need to reduce uncertainty in $\mathrm{CO}_{2}$ flux from the present $40-50 \%$ to $10-15 \%$. Furthermore, there is a need for estimation with adequate accuracy of seasonally unbiased $\mathrm{CO}_{2}$ flux values for individual years. Sea surface carbon measurements onboard research vessels and fixed stations were carried out from the late 1950s [94]. In the 1990s, autonomous measurements of $\mathrm{pCO}_{2}$ at the surface on commercial vessels started to be a common practice [95]. During the last decade, the number of underway measurements from commercial ships and research vessels as well as at fixed stations has increased significantly and was complemented by data from Lagrangian drifting buoys, particularly useful in the Southern Ocean [96].

The performance of the air-sea gas transfer algorithms is still not as advanced as for the physical fluxes (Fig. 2). The gas transfer velocities are uncertain by about $100 \%$ for winds of $15 \mathrm{~ms}^{-1}$ [97]. Significant progress has been made in the parameterisation of sea salt aerosol fluxes [98]. However, recent formulations converge to only about a factor of 3-5, and more measurements are required in a variety of different conditions. Opportunistic efforts taking advantage of $\mathrm{O}_{2}$ 
disequilibria are arising from biological productivity. Radon deficit methods or utilizing ${ }^{14} \mathrm{C}$ excesses in the atmosphere resulting from bomb tests [99,100 and 101] have provided valuable information on air sea gas exchange. Waterside tracer release techniques can provide regional gas exchange estimates [102]. Information on regional or global phenomena that occur over seasonal to decadal timescales is obtained from upscaling field studies.

\subsection{Observationally derived climatologies of $\mathrm{CO}_{2}$ flux}

The most recent global compilation of air-sea $\mathrm{CO}_{2}$ flux [103] is based on about 3.0 million measurements of surface water $\mathrm{pCO}_{2}$ obtained since the early 1970 s, i.e. 3 times more than in [104] (Fig. 6). Nevertheless, the observations are still distributed inhomogeneously with the highest density in the North Atlantic and North Pacific. This new climatology reveals that the strongest $\mathrm{CO}_{2}$ flux into the ocean occurs in the North Atlantic subpolar regions and resolves the annual cycle of $\Delta \mathrm{pCO}_{2}$ and net $\mathrm{CO}_{2}$ flux whose magnitudes may exceed annual mean values. Error analysis gives a random error for the global flux of about $13 \%$ of the net global ocean uptake. In the near future annual $\mathrm{CO}_{2}$ fluxes will be derived from the integration of data from regular SOOP (Ship of Opportunity Program) lines (Fig. 7a) and time series stations \& moorings (Fig. 7b) with Lagrangian wave surfers and surface buoys [94]. Optimization of sampling rate and integration will make use of models and proxy variables [105].

Temporal interannual changes in $\mathrm{CO}_{2}$ fluxes are apparent for many regions. Sea surface $\mathrm{pCO}_{2}$ increases in the North Atlantic over the last decade, have been higher than the atmospheric $\mathrm{pCO}_{2}$ increase [106, 107, 108 and 109]. Similarly, in the Southern Ocean oceanic $\mathrm{pCO}_{2}$ growth rates have been observed to be equal or greater than the atmospheric rate [112]. The differences between these regional studies and the global scale assessments by [103] emphasise the sensitivity of the results to sampling and assessment scales. Efforts to determine the interannual variability in the $\mathrm{CO}_{2}$ fluxes (and $\mathrm{pCO}_{2}$ ) have started in the tropical Pacific, North Atlantic [110 and 111] and South Indian [112], but most areas lack sufficient data and synoptic global scale assessments are not possible.
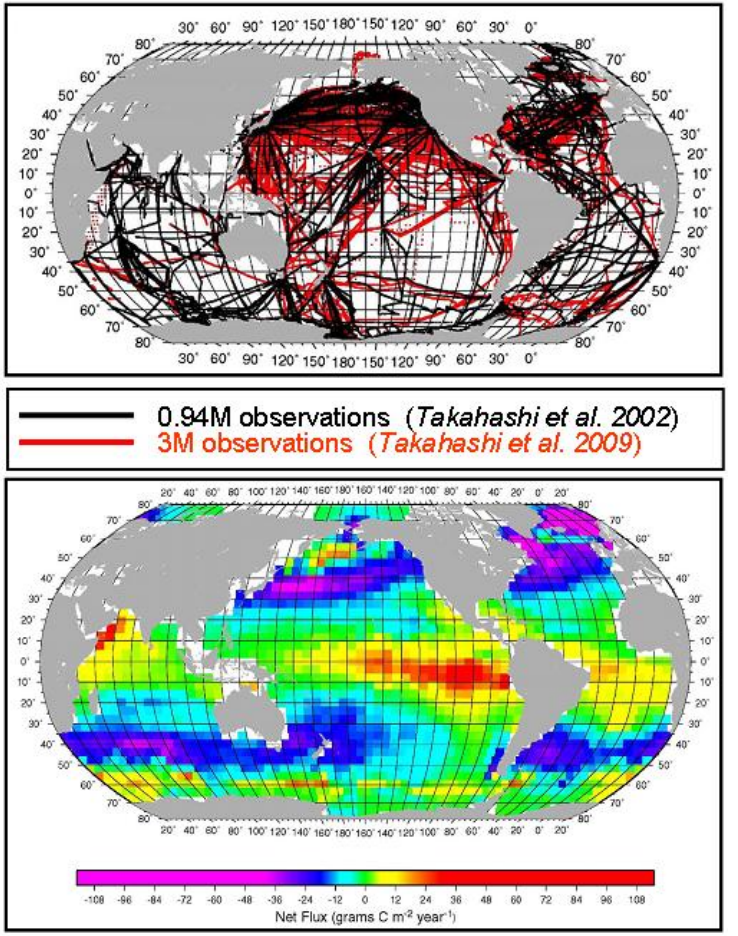

Figure 6. Ship observations used for the Takahashi et al. (2002) climatology (black) and for Takahashi et al. (2009) climatology (red) (top panel) and annual mean CO2 sea-air flux in Takahashi et al. (2009) climatology. Adopted from Takahashi et al. (2009)

\subsection{Remote sensing of air-sea gas fluxes}

Global and regional sea surface $\mathrm{pCO}_{2}$ and air-sea fluxes are often estimated using algorithms relating sea surface $\mathrm{pCO}_{2}$ [94] to satellite-derived parameters and reanalyses [113] and neural network approaches [114]. Algorithms have been developed and applied to calculate particulate carbon [115 and 116] and coloured organic matter [117] in near-surface waters from satellite measurements of water-leaving radiance. The accuracy of these measurements depends on sensor characteristics. SeaWiFS (Sea-viewing Wide Field of View Sensor), MODIS-Aqua (MODIS-EOS (Earth Observing System) PM) and MERIS (Medium Resolution Imaging Spectrometer) instruments have been successfully used for these measurements. Future sensors are expected to have more spectral bands that will lead to improved calculations of particulate carbon and coloured organic matter. 

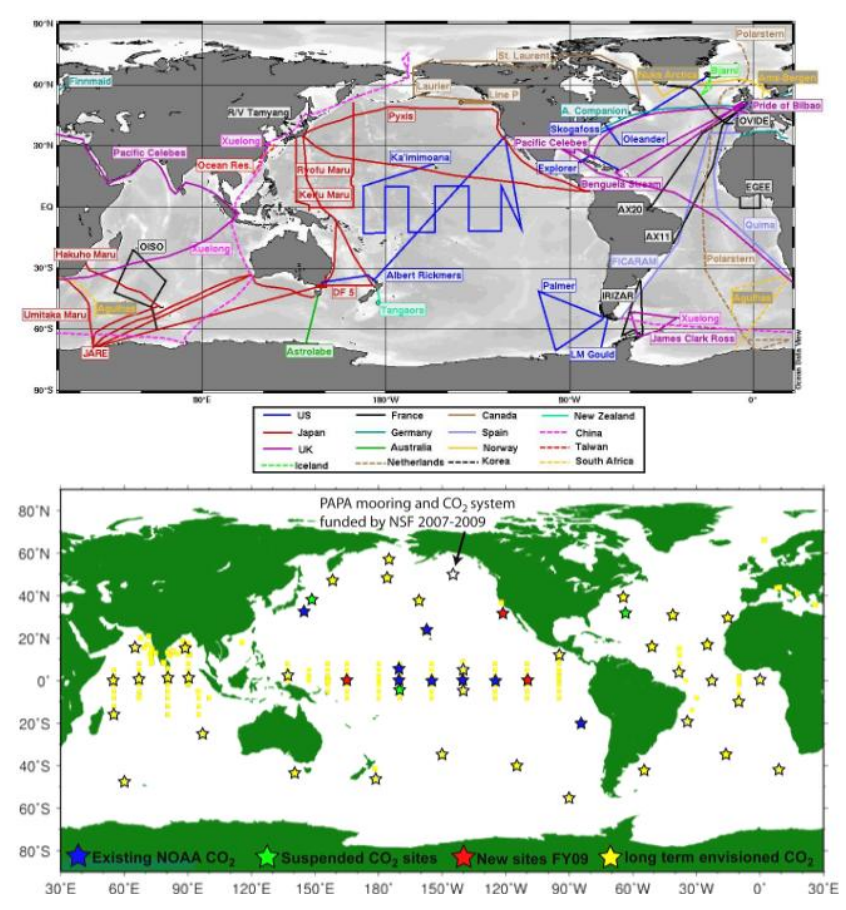

Figure 7. Present regular SOOP/VOS lines (top panel) and time series stations \& moorings (bottom panel)

\subsection{Surface $\mathrm{CO} 2$ fluxes from numerical modelling}

For the ocean-atmosphere $\mathrm{CO}_{2}$ fluxes, numerical models [105, 118 and 119], are emerging as an effective way to optimize the spatial and temporal sampling scales of surface $\mathrm{pCO}_{2}$ required to achieve the $10-15 \%$ uncertainty levels in $\mathrm{CO}_{2}$ fluxes. Modelled signal-tonoise ratios of oceanic $\mathrm{pCO}_{2}$ highlight the difficulty in separating scales of variability. An approach combining the signal-to-ratios with Fourier transforms [105] showed that in different regions, a trade-off between temporal and spatial sampling exists, and this can be exploited to formulate a strategy that returns the maximum information for minimal sampling effort.

\section{SATELLITE OBSERVATIONS OF SEA ICE}

A comprehensive review of sensors and the accuracy of observations of sea ice from satellites [120] stress that the most reliable data on ice concentrations is available from microwave radiometers (e.g. SSM/I) with an accuracy of 1 to $6 \%$ in winter [121]. The sea ice concentration analysis based on passive microwave from SMMR (Scanning Multifrequency Microwave Radiometer) (from 1979-1988) and SSM/I (DMSP (Defense Meteorological Satellite Program) program from 1987) are the backbone of sea ice climate records. Products are available from, e.g. NSIDC (National Snow and Ice Data Center) (http://nsidc.org/) and the OSI SAF (Ocean and Sea Ice Satellite Application Facility) (http://saf.met.no/). Figure 8 shows the Arctic summer sea ice extent with respect to the $1979-2000$ average. In September 2007 the Arctic sea ice reached the minimum extent in the history based on satellite data. The DMSP program will provide data until at least 2017. Higher spatial resolution is obtained from the AMSR-E (Advanced Microwave Scanning Radiometer for EOS (Earth Observing System) which will be followed up by AMSR-2 on the GCOM-W (Global Change Observation Mission - Water) program in 2011 (http://www.jaxa.jp/projects/sat/gcom/)

Direct mapping of the ice thickness from space by penetrating the ice column is difficult [120]. Since 2003, the ICESat mission equipped with a laser altimeter has made it possible to estimate ice elevation relative to that of the local sea surface giving a good estimate of the total freeboard (the vertical distance between the sea surface and the air/snow interface). Together with the snow loading this gives an estimate of the total ice thickness [122, 123 and 124]. Figure 9 shows the spatial distributions of sea ice thickness derived from two ICESat campaigns acquired during the fall 2005 and the winter 2006. It demonstrates that there are significant changes in the ice thickness in addition to those in sea ice extent. The CryoSat-2 mission planned to be launched in 2010 will also provide estimates of the thickness of floating sea ice by measuring the freeboard of ice. Use of Synthetic Aperture technique (SIRAL, SAR (Synthetic Aperture Radar)/Interferometric Radar Altimeter) will enable measurements of high spatial resolution $(250 \mathrm{~m})$ compared to standard altimeters (see http://www.esa.int/esaLP/). The upcoming CryoSat-2 and ICESat-2 missions will provide extensive coverage of this ice parameter in the Arctic into the next decade.

Sea ice motion observations are required to understand ice export and the large scale advection balance. Buoys moored on Arctic ice since 1979 (about twenty per year) under the International Arctic Buoy Program provide considerably undersampled picture of the ice drift. In this respect satellites can provide a complementary representation of the ice drift. These are based on dynamical-statistical methodologies for tracking ice features on sequential satellite maps also [120]. The drifts during the cold period can be obtained from radiometers (e.g. SSM/I (85 GHz) and AMSR-E (89 $\mathrm{GHz})$ ) while warm season sensitivity of these high frequency channels limits their effectiveness in measuring drifts [125 and 126]. Scatterometer data can also be used to estimate sea ice drift from daily backscatter maps [126]. Sea ice drift inferred from satellite data has a reasonable accuracy but is limited by data gaps and low data density at the beginning and the end of the winter growth season.

Ice drift time series and routinely updated products are available from e.g. http://cersat.ifremer.fr/ and from 
http://nsidc.org/ [127]. Ice drift datasets are used in climate models for validation and to estimate sea ice flux [125] and to improve sea ice models at large scales [128 and 129]. Faster ice-drift, more variable ice conditions, and a moister atmosphere make tracking more difficult in the Antarctic. However, Antarctic fields have been produced [127], although with higher level of errors than in the Arctic.

\section{VISION FOR THE FUTURE}

\subsection{Improvements to Flux Parameterizations}

Further development is required to account for a wider range of conditions and to include all significant processes, including wind-wave coupling. Since parameterizations of turbulent fluxes are often applied to the space-time averaged variables, there is a need to account for non-linearities in flux parameterisations. Non-turbulent mechanisms of sea-air mass transfer associated with sea spray must also be considered.

This implies the need for continuing efforts to measure in-situ air-sea fluxes in different regions and under a wide range of weather conditions, including highly variable regions of the western boundary currents [135], ice marginal areas and over sea ice. In situ radiative flux measurements are needed both for satellite validation and for improved parameterisation of radiation from observations and should account for both cloud cover and cloud types. More measurements of surface ocean and atmospheric $\mathrm{pCO}_{2}$ are needed to facilitate the development of both new parameterisations and of high spatial resolution global $\mathrm{CO}_{2}$ air-sea flux products. This is likely to be achieved through the integration of platforms and models.

\subsection{In-situ Flux and Related Parameter Measurements}

For buoy observing systems, improved sensors for long-term deployments should be a priority following the requirements formulated in [4]. Further requirements are the installation of turbulent flux sensors, active levelling of radiometer mounts and the use of heaters and de-icers to cope with ice and freezing sea spray.

With increased power, buoys will be able to support more routine deployments of infrared gas analyzers (for $\mathrm{CO}_{2}$ and $\mathrm{H}_{2} \mathrm{O}$ ), and, potentially, more advanced flux sensors using remote sensing or in situ analyzer methodologies. The measurement of aerosol fluxes [130] and the coincident measurement of chemical and physical fluxes will become increasingly important. Increasing number of deployments of Flux Reference Buoys is required in the western boundary current extensions and high latitudes. The NOAA Kuroshio Extension Observatory (KEO) [135] should remain the prototype for the development of existing and deployment of new observational networks.

Simultaneously, sustaining TAO/TRITON, PIRATA and RAMA as part of GOOS and GCOS will be a challenge. These observing systems need to continually evolve and new institutional arrangements, such as the establishment of national climate services, may be required to continue these observing systems into the future.

The research quality underway observing system must also be further developed. There is an urgent need to agree on the effective design and implementation of this system, which will ensure an effective involvement of as many nations as possible, and the uniform application of the SAMOS data management model to all observations collected. Solutions suggested by [16] span from a distributed network to a centralized SAMOS Data Assembly Center (DAC).

Of specific importance is the development of costeffective systems for measuring precipitation at sea [4]. Major issues are how to distinguish rain from spray as winds pick up speed, and the need for a level platform. Funnel rain gauges can be effective but should ideally be deployed alongside optical rain gauges, which are still expensive. Underwater acoustic sensors have shown some promise [131].

It is also critical to properly and continually adopt the best practices for deploying sensors on ships and buoys [24]. This may be facilitated by the application of the results of computer modelling of wind flow distortion [32]. Data quality assurance and traceability of each sensor calibration to a standard is vital.

There is a need to expand routine carbon measurements from commercial and research vessels and fixed stations to moorings, buoys, and floats to meet sampling requirements. Until reliable sensors on autonomous platforms are available, the global surface carbon observation network will need to aim at strengthening the reliable and high quality underway systems. Of particular note are improvements in techniques that measure gas fluxes on minute timescales [132]. Further discussion on the sensors and systems for marine $\mathrm{CO}_{2}$ observations is provided by [133].

The degradation of the VOS observing system over the last two decades (seen in both the decrease in the number of ships recruited and decrease of the number of variables reported) raises an alarm for immediate action to reinvigorate the VOS programme as a sustained module of ocean observation and prediction. Continuing 
degradation of the VOS system will considerably restrict the usefulness of further developments in higher accuracy observing systems

VOS instrumentation should be continually but more judiciously improved taking into account results from the systems providing research quality observations including initiatives such as SAMOS. In this respect, all challenges for research vessels are also the challenges for VOS instrumentation, albeit difficult to achieve in the short term. VOSClim [25] should be maintained to identify and spread good observing practice for VOS. The importance of timely availability of observational metadata should be recognized by WMO (World Meteorological Organization) and its Joint (with IOC (International Oceanographic Commission)) Technical Commission for Oceanography and Marine Meteorology (JCOMM) and sufficient resources allocated to metadata distribution (e.g., separating rapid electronic metadata delivery from formal WMO publication, which could follow later).

\subsection{Development of Satellite Surface Flux and Ice Measurements}

Within the next few years three new scatterometers (OceanSat2, FY2 (FengYun = wind and cloud), and CFOSAT (Chinese-French Oceanographic SATellite), and two SARs (Tandem-X and TerraSAR-X-2 are anticipated; however QuikSCAT has ceased to function, and it is likely that several other radiometers will also reach the end of their lifetimes [46]. The loss of QuikSCAT was expected to result in an 80 to $90 \%$ loss in detection capability for hurricane force winds from extratropical cyclones. Thus, high priority should be given to the replacement of a Ku-band capability in space. Data from OceanSat-2 or HY2 could compensate for this loss if the accuracy of the data is sufficiently good and it is shared in near real time.

In the intermediate term (4-10 years) the launch of PostEPS and DFS scatterometers are expected. The availability of co-located $\mathrm{Ku}$ and $\mathrm{C}$ band data from DFS, and rain rates from AMSR3 on the same satellite, would allow for climate quality inter-calibration with historical $\mathrm{Ku}$ and $\mathrm{C}$ band radars.

Problems with retrieving air temperature and humidity are still likely to limit the accuracy of satellite-based surface fluxes. In this respect, the future improvement of SSM/I-like retrievals is important. This is also true for satellite precipitation whose retrievals currently rely on coastal and island-based radar sites and moored buoys [65]. A renewed effort to improve shipboard rain gauges and to develop new types would be required.

Future challenges in sea ice remote sensing with SAR are associated with a new generation of missions such as RADARSAT-2, Sentinel-1, PALSAR (Phased Array type L-band Synthetic Aperture Radar) and TerraSARX [120]. Carefully conducted field campaigns along with backscattering modeling will be needed to fully understand the potential of multisensor-frequency SAR. Accurate estimation of snow depth on sea ice is important when measuring sea ice thickness. An accurate snow thickness product could be obtained using theoretical emissivity modeling and a thermodynamic snow/ice model in combination with the radiometer data. Better estimation of snow cover volumetric wetness in the marginal sea ice zones using modeling, SAR and radiometer data is needed [120].

The future of sea ice Data Assimilation systems will be in two main areas: (1) development of techniques to incorporate as many operational observations as feasible and (2) improving the prior estimate or equivalently the forecasts provided by coupled atmosphere-ice-ocean models that propagate information from past observations [120].

\subsection{Development of NWP Flux Products}

The next decade will be marked by new NWP products from the major meteorological centers [10]. These will be based on better performing models with higher spatial resolution. NCEP CFSRR will cover the period 1979-2009 with high horizontal and vertical resolution (T382L64) and will assimilate radiance measurements from the historical satellites. The NASA Modern Era Retrospective-Analysis for Research and Applications (MERRA) to be completed soon will have resolution of $0.667^{\circ}$ longitude by $0.5^{\circ}$ latitude with 72 levels up to a pressure of $0.01 \mathrm{hPa}$.

The ECMWF's next generation reanalysis system (presumably, Re-Analysis (ERA) project ERA-75) will span a 75-year period, extending back in time to the first half of the $20^{\text {th }}$ century. The second Japanese atmospheric reanalysis project JRA-55 (Japanese 55year reanalysis project) has started in 2009. Furthermore, NOAA-CIRES (National Oceanic and Atmospheric Administration-Cooperative Institute For Research In Environmental Sciences) will continue the historical reanalysis project, the Twentieth Century Reanalysis Project (C20r) aimed at the development of a six-hourly, four-dimensional global atmospheric dataset spanning 1891-2008 to place current atmospheric circulation patterns into a historical perspective [134].

Improvement of parameterization in atmospheric models is a prerequisite for improved coupled models. As reanalyses venture into coupling, more focus can be expected on surface fluxes and their errors. The next decade will probably require extremely high resolution 
(T799 or higher) reanalyses, at least for shorter periods, in order to test the impact of the actual high resolution forcing on high-resolution numerical experimentation with ocean models.

The need for improvement of air-sea gas flux products requires a strengthening of forecast numerical model capabilities, including those used to constrain the oceanland partitioning of carbon. Confidence in forecasting capabilities of numerical models for future evolution of atmospheric $\mathrm{CO}_{2}$ and the changing role of the ocean will depend to a significant extent on the data sets available to constrain coupled climate carbon models.

\subsection{Regional Vision of Future Observing Systems}

Western Boundary Current Extensions are key locations for air-sea interaction in mid-latitudes, where high spatial and temporal resolution is necessary to capture first order features [135]. The Gulf Stream, Kuroshio, Agulhas, East Australian Current system and the Brazil-Malvinas Confluence (Fig. 5) WBCE (Western Boundary Current Extension) observing systems would include a range of platforms to improve assimilation products and their validation, and to identify the relevant processes that impact the climate system in these regions of very intense air-sea interaction.

A further key regional focus for enhanced observations should be the high latitude oceans of both hemispheres. This focus is particularly justified by the recent establishment of the US CLIVAR Working Group on High Latitude Surface Fluxes. Flux observations in high latitudes require instrumentation able to withstand high winds, extremely rough seas, and cold temperatures. The importance of surface fluxes in high latitudes for ocean and atmospheric variability is justified by the extremely weak stratification of both the ocean and atmosphere resulting in a very strong influence of surface fluxes on convective processes.

Of a special importance will be the improvement of the quantitative estimation of surface fluxes from all sources in coastal areas. These products are highly important for operational applications.

\section{Recommendations}

8.1. In-situ Observing System for Surface Fluxes. This system consists of many elements with different levels of accuracy, complexity and sampling capability. It must be maintained and enhanced, where possible, according to the following specific actions points:

- Consideration should be given to expanding OceanSITES to the subpolar and high latitudes.
This should include direct turbulent measurements of energy, gas and particle fluxes. More Flux Reference sites should be considered in TAO/TRITON, PIRATA and RAMA networks with data and metadata management being more seamlessly integrated. The actual accuracy of buoy flux measurements should be properly quantified.

- The SAMOS-like research vessel programmes should be developed into a truly international system. Transfer of technologies to selected commercial and other non-research vessels is essential.

- The dramatic decline in the VOS programme must be recognised and addressed. The programme should be re-invigorated to provide, as standard, the complete ship meteorological report including all measured and visually observed variables and complete metadata (including ship identifier) and to ensure their integration into ICOADS. The VOSClim sub-programme should continue to be maintained and expanded though the recruitment of more ships. Technologies and good observing practices should be transferred from specialized buoy and ship measurements to the large scale VOS scheme.

- Advances in sensor and instrument development should be used to enhance the density of the global surface ocean carbon observing network through deployment on additional key SOOP lines, moorings, Lagrangian platforms, gliders and profiling floats.

\subsection{Satellite Observing System for Surface Fluxes} should provide continuous records of global highresolution scatterometry and microwave measurements with priorities for research to improve retrievals of nearsurface temperature and humidity, precipitation and whitecaps and improved sampling for vector winds. Passive microwave imaging for sea ice must continue to be maintained along with improved access to SAR data. Periods of operation should overlap to provide homogeneity of time series. More power is needed for continuous improvement of surface radiative flux products developed under ISCCP and other activities.

8.3. Improved Surface Flux Parameterizations. More direct flux measurements are needed for air-sea gas and particle exchanges and under high wind conditions. Wave characteristics should be incorporated into parameterizations of the turbulent fluxes and sea surface albedo. Improved parameterisations of near-surface variations of ocean temperature with depth are needed.

8.4. Global and Regional Surface Flux Product Evaluations. It is vital that different surface flux products from various sources are evaluated using a common methodology, which makes use of both high 
quality, buoy measurements and large scale hydrographic constraints [136]. Improvements to dataset construction methods are needed including statistical techniques for homogenization of sampling and minimization of sampling errors.

\subsection{Annual Assessment of Changing Sea Surface} $\mathrm{CO}_{2}$ and air-sea $\mathrm{CO}_{2}$ fluxes. The next decade should deliver seasonally unbiased annual assessments of the regional and global trends in ocean - atmosphere carbon fluxes. This will require:

- implementing integrated multi-platform global observing network that will reduce uncertainty in regional and global $\mathrm{CO}_{2}$ flux estimates to $10-15 \%$ of current values (Globally $\approx 2 \mathrm{Pg} \mathrm{C} \mathrm{yr}^{-1}$ ).

- new observational capabilities to increase the density of global surface ocean carbon observing networks to the required level as well as improved understanding of the biogeochemical / physical mechanisms driving surface ocean $\mathrm{fCO}_{2}$ and air-sea flux variability;

- $\quad$ provision of data that will better constrain coupled climate carbon models in their ability to forecast changes in the ocean uptake of $\mathrm{CO}_{2}$ and the effectiveness of $\mathrm{CO}_{2}$ emission mitigation strategies.

8.6. NWP and Reanalyses Fluxes. The space-time resolution and accuracy of these products should be improved. Better accuracy will be only possible if the whole NWP system configuration and not surface flux parameterizations per se is improved. Uncertainties of NWP flux products should be quantitatively assessed through evaluation against high quality flux data. Coupled reanalyses hold the best prospect for spurring real NWP advances in a manner that reduces biases due to currents and waves.

\section{ACKNOWLEDGEMENTS}

The authors express their gratitude to all contributing authors of the CWPs used for the preparation of this Plenary White Paper. Our special thanks to Claus Boening, Armin Koehl, Bill Large, Wade McGillis, Vladimir Ryabinin, Detlef Stammer, Bob Weller, Steve Yeager, Lisan $\mathrm{Yu}$ and anonymous reviewers whose constructive comments largely improved this paper.

\section{REFERENCES}

[1] Taylor, P.K., Bradley, E.F., Fairall, C.W., Legler, L., Schulz, J., Weller, R.A. and White, G.H. (2001) Surface fluxes and surface reference sites. In, Koblinsky, C.J. and Smith, N.R. (eds.) Observing the Oceans in the 21st Century. Melbourne, Australia, GODAE Project Office/Bureau of Meteorology, 177197.
[2] Taylor, P. K., (Editor), 2000: Intercomparison and validation of ocean-atmosphere energy flux fieldsFinal report of the Joint WCRP/SCOR Working Group on Air-Sea Fluxes. WCRP-112, WMO/TD-1036, 306 pp.

[3] Weller, R.A., E.F. Bradley, and R. Lukas, 2004: The interface or air-sea flux component of the TOGA Coupled Ocean-Atmosphere Response Experiment and its impact on subsequent air-sea interaction studies. J. Atmos. Oceanic Tech., 21, 223-257.

[4] Fairall, C. \& Co-Authors (2010). "Observations to Quantify Air-Sea Fluxes and their Role in Climate Variability and Predictability" in these proceedings (Vol. 2), doi:10.5270b/OceanObs09.cwp.27.

[5] Bindoff, N.L., J. Willebrand, V. Artale, A, Cazenave, J. Gregory, S. Gulev, K. Hanawa, C. Le Quéré, S. Levitus, Y. Nojiri, C.K. Shum, L.D. Talley and A. Unnikrishnan, 2007: Observations: Oceanic Climate Change and Sea Level. In: Climate Change 2007: The Physical Science Basis. Contribution of Working Group I to the Fourth Assessment Report of the Intergovernmental Panel on Climate Change [Solomon, S., D. Qin, M. Manning, Z. Chen, M. Marquis, K.B. Averyt, M. Tignor and H.L. Miller (eds.)]. Cambridge University Press, Cambridge, United Kingdom and New York, NY, USA.

[6] Gulev, S.K., B. Barnier, J.-M. Molines, T. Penduff, J. Chanut, 2007: Impact of spatial resolution of simulated surface water mass transformation in the Atlantic. Ocean Modelling, 19, 138-160.

[7] Large, W.G., Nurser, A.J.G., 2001. Ocean surface water mass transformation. In: Siedler, G., Church, J., Gould, J. (Eds.), Ocean Circulation and Climate. Academic Press, pp. 317-336.

[8] Marsh, R., Josey, S.A., Nurser, A.J.G., de Cuevas, B.A., Coward, A.C., 2005. Water mass transformation in the North Atlantic over 1985-2002 simulated in an eddypermitting model. Ocean Sci. 1, 127-144.

[9] Lagerloef, G.S.E., 1988: Final Report of the First Workshop Salinity Sea Ice Working Group (SSIWG), La Jolla, CA, USA, 7-8 February 1998. http://www.esr.org/lagerloef/ssiwg/ssiwgrep1.v2.html

[10] Trenberth, K. \& Co-Authors (2010). "Atmospheric Reanalyses: A Major Resource for Ocean Product Development and Modeling" in these proceedings (Vol. 2), doi:10.5270/OceanObs09.cwp.90.

[11] Swail, V. \& Co-Authors (2010). "Wave Measurements, Needs and Developments for the Next Decade" in these proceedings (Vol. 2), doi:10.5270/OceanObs09.cwp.87.

[12] Brooks, I., and multi., 2009: Physical Exchanges at the Air-Sea Interface UK-SOLAS Field Measurements. Bull. Amer. Met. Soc., 90, 629-644.

[13] Yelland, M.J.; Pascal, R.W.; Taylor, P.K.; Moat, B.I. 2009: AutoFlux: an autonomous system for the direct measurement of the air-sea fluxes of $\mathrm{CO}_{2}$, heat and momentum. J. Oper. Oceanogr. 2, 15-23. 
[14] Fairall, C. W., E. F. Bradley, J. E. Hare, A. A. Grachev, and J. B. Edson, 2003: Bulk parameterization of airsea fluxes: Updates and verification for the COARE algorithm. J. Clim., 16, 571-591.

[15] Andreas, EL, P.O.G. Persson, and J.E. Hare, 2008: A bulk turbulent air-sea flux algorithm for high-wind, spray conditions. J. Phys. Oceanogr., 38, 1581-1596.

[16] Smith, S. \& Co-Authors (2010). "The Data Management System for the Shipboard Automated Meteorological and Oceanographic System (SAMOS) Initiative" in these proceedings (Vol. 2), doi:10.5270/OceanObs09.cwp.83.

[17] McPhaden, M. \& Co-Authors (2010). "The Global Tropical Moored Buoy Array" in these proceedings (Vol. 2), doi:10.5270/OceanObs09.cwp.61.

[18] Bourlès, B., R. Lumpkin, M.J. McPhaden, F. Hernandez, P. Nobre, E. Campos, L. Yu, S. Planton, A. Busalacchi, A.D. Moura, J. Servain, and J. Trotte, 2008: The Pirata Program: History, accomplishments, and future directions. Bull. Amer. Meteor. Soc., 89, $1111-1125$.

[19] Josey, S. A., R. W. Pascal, P. K. Taylor and M. J. Yelland, 2003: A New Formula For Determining the Atmospheric Longwave Flux at the Ocean Surface at Mid-High Latitudes. Journal of Geophysical Research., 108(C4) doi:10.1029/2002JC001418.

[20] Pinker, R.T., H. Wang, and S. A. Grodsky, 2009: How good are ocean buoy observations of radiative fluxes? Geophys. Res. Lett., 36, L10811, doi:10.1029/2009GL037840

[21] Grachev, A.A. Andreas, E.L., Fairall, C.W., Guest, P.S., Persson, P.O.G., 2007: SHEBA flux-profile relationships in the stable atmospheric boundary layer. Boundary-Layer Meteorology, 124, 3, 315-333.

[22] Gille, S. \& Co-Authors (2010). "Surface Fluxes in High Latitude Regions" in these proceedings (Annex).

[23] Weller, R. A., E. F. Bradley, J. B. Edson, C. W. Fairall, I. Brooks, M. J. Yelland and R. W. Pascal, 2008: Sensors for physical fluxes at the sea surface: energy, heat, water, salt. Ocean Science, 4, 247-263.

[24] Bradley, F. and C. Fairall, 2007: A Guide to Making Climate Quality Meteorological and Flux Measurements at Sea. NOAA Technical Memorandum OAR PSD-311, NOAA/ESRL/PSD, Boulder, CO, 108 pp.

[25] Kent, E. \& Co-Authors (2010). "The Voluntary Observing Ship (VOS) Scheme" in these proceedings (Vol. 2), doi:10.5270/OceanObs09.cwp.48.

[26] Woodruff, S. \& Co-Authors (2010). "Surface In Situ Datasets for Marine Climatological Applications" in these proceedings (Vol. 2), doi:10.5270/OceanObs09.cwp.93.

[27] Send, U. \& Co-Authors (2010). "OceanSITES" in these proceedings (Vol. 2), doi:10.5270/OceanObs09.cwp.79.

[28] Feely, R.A., T. Takahashi, R. Wanninkhof, M.J.
McPhaden, C.E. Cosca, S.C. Sutherland and M.-E. Carr, 2006: Decadal Variability of the Air-Sea CO2 Fluxes in the Equatorial Pacific Ocean. J. Geophys. Res., 111, C08S90, doi:10.1029/2005JC003129.

[29] Lee, C. \& Co-Authors (2010). "Autonomous Platforms in the Arctic Observing Network" in these proceedings (Vol. 2), doi:10.5270/OceanObs09.cwp.54.

[30] Berry, D.I., E.C. Kent, and P.K. Taylor, 2004: An analytical model of heating errors in marine air temperatures from ships. J. Atmos. Oceanic Tech., 21, 1198-1215.

[31] Moat, B. I., M.J. Yelland, R.W. Pascal, and A.F. Molland, 2005: An overview of the airflow distortion at anemometer sites on ships. Int. J. Climatol., 25, 997-1006.

[32] Yelland, M.J., B.I. Moat, R.W. Pascal, and D.I. Berry, 2002: CFD model estimates of the airflow distribution over research ships and the impact on momentum flux measurements. J. Atmos. Oceanic Tech., 19, 14771499.

[33] Worley, S. J., S. D. Woodruff, R. W. Reynolds, S. J. Lubker, and N. Lott, 2005: ICOADS Release 2.1 data and products. Int. J. Climatol., 25, 823-842.

[34] Kent, E.C., P. K. Taylor, B. S. Truscott, and J. S. Hopkins, 1993: The accuracy of voluntary observing ships' meteorological observations-Results of the VSOP-NA. J. Atmos. Oceanic Technol., 10, 591-608.

[35] Kent, E.C., and D. I. Berry, 2005: Quantifying random measurement errors in voluntary observing ship meteorological observations. Int. J. Climatol., 25, 843-852.

[36] Kent, E. C., S. D. Woodruff and D. I. Berry, 2007: WMO Publication No. 47 Metadata and an Assessment of Voluntary Observing Ships Observation Heights in ICOADS, Journal of Atmospheric and Oceanic Technology, 24(2), 214-234.

[37] Josey, S. A., E. C. Kent, and P. K. Taylor, 1999: New insights into the ocean heat budget closure problem from analysis of the SOC air-sea flux climatology. $J$. Climate, 12, 2856-2880.

[38] Isemer, H._J., J. Willebrand, and L. Hasse, 1989: Fine adjustment of large scale air-sea energy flux parameterizations by direct estimates of ocean heat transport. J. Climate, 2, 1173-1184.

[39] Grist, J.P., and S.A. Josey, 2003: Inverse Analysis Adjustment of the SOC Air-Sea Flux Climatology Using Ocean Heat Transport Constraints. J. Climate, 16, 3274-3295.

[40] Gleckler, P., and B. Weare, 1997: Uncertainties in global ocean surface heat flux climatologies derived from ship observations. J. Climate, 10, 2764-2781.

[41] Kent, E.C., P. Challenor, and P. K. Taylor, 1999: A statistical determination of the random errors present in VOS meteorological reports. J. Atmos. Oceanic Technol., 16, 905-914. 
[42] Gulev, S.K., T. Jung, and E. Ruprecht, 2007: Estimation of the impact of sampling errors in the VOS observations on air-sea fluxes. Part I. Uncertainties in climate means. J. Climate, 20, 279-301.

[43] Gulev, S.K., T. Jung, and E. Ruprecht, 2007: Estimation of the impact of sampling errors in the VOS observations on air-sea fluxes. Part II. Impact on trends and interannual variability. J. Climate, 20, 302315 .

[44] Berry, D.I. and Kent, E.C., 2009: A new air-sea interaction gridded dataset from ICOADS with uncertainty estimates. Bulletin of the American Meteorological Society 90, (5), 645-656.

[45] Berry, D.I. and Kent, E.C., 2010: Air-Sea Fluxes from ICOADS: The Construction of a New Gridded Dataset with Uncertainty Estimates, International Journal of Climatology, Early Online, doi:10.1002/joc.2059.

[46] Bourassa, M. \& Co-Authors (2010). "Remotely Sensed Winds and Wind Stresses for Marine Forecasting and Ocean Modeling" in these proceedings (Vol. 2), doi:10.5270/OceanObs09.cwp.08.

[47] Zhang, H.-M., R. W. Reynolds, and J. J. Bates, 2006b: Blended and gridded high resolution global sea surface wind speed and climatology from multiple satellites: 1987 - present. American Meteorological Society 2006 Annual Meeting, Atlanta, GA, P2.23.

[48] Jackson, D. L., G. A. Wick, and J. J. Bates, 2006: Nearsurface retrieval of air temperature and specific humidity using multisensor microwave satellite observations. J. Geophys. Res., 111, D10306, doi:10.1029/2005JD006431.

[49] Anderson, A., S. Bakan and C. Klepp, The HOAPS Climatology. Flux News, 4, 10-13.

[50] Kubota, M., N. Iwabe, M. Cronin, and H. Tomita, 2008: Surface heat fluxes from the NCEP/NCAR and NCEP/DOE reanalyses at the Kuroshio Extension Observatory buoy site. J. Geophys. Res., 113, C02009, doi:10.1029/2007JC004338.

[51] Chou, S.H., E. Nelkin, J. Ardizzone, and R.M. Atlas, 2004: A Comparison of Latent Heat Fluxes over Global Oceans for Four Flux Products. J. Climate, 17, 3973-3989.

[52] Bentamy A., K B. Katsaros, M. Alberto, W. M. Drennan, E. B. Forde, and H. Roquet, 2003: Satellite Estimates of wind speed and latent heat flux over the global oceans, J. Climate, 16, $637-656$.

[53] Bouras, D., L. Eymard, and W. T. Liu, 2002: A neural network to estimate the latent heat flux over oceans from satellite observations. Int. J. Remote Sens., 23, 2405-2423.

[54] Bouras, D., 2006: Comparison of Five Satellite-Derived Latent Heat Flux Products to Moored Buoy Data. $J$. Climate, 19, 6291-6313.

[55] Zhang, Y.-C., W. B. Rossow, A. A. Lacis, V. Oinas, and M. I. Mishchenko, 2004: Calculation of radiative fluxes from the surface to top of atmosphere based on
ISCCP and other global data sets: Refinements of the radiative transfer model and the input data. $J$.

Geophys. Res., 109, D19105,

doi:10.1029/2003JD004457.

[56] Ghate, V., B.A. Albrecht, C.W. Fairall, and R.A. Weller, 2009: Cloud fraction climatology and its indicators in South-East Pacific Ocean. J. Clim., to appear.

[57] Kato, S, F.G. Rose, D.A. Rutan, and R.P. Charlock, 2008: Cloud effects on the meridional atmospheric energy budget estimated from Clouds and the Earth's Radiant Energy System (CERES) data. J. Clim., 21, 42234241.

[58] Trenberth, K. E., J. T. Fasullo, and J. Kiehl, 2009: Earth's global energy budget. Bull. Amer. Meteor. Soc., in press. doi:10.1175/2F2008BAMS2634.1

[59] Xie, P., and P.A. Arkin, 1996: Analyses of global monthly precipitation using gauge observations, satellite estimates, and numerical model predictions. $J$ Clim., 9, 840-858.

[60] Adler, R.F., G.J. Huffman, A. Chang, R. Ferraro, P. Xie, J. Janowiak, B. Rudolf, U. Schneider, S. Curtis, D. Bolvin, A. Gruber, J. Susskind, and P. Arkin, 2003: The Version 2 Global Precipitation Climatology Project (GPCP) Monthly Precipitation Analysis (1979Present). J. Hydrometeor., 4, 1147-1167.

[61] Joyce, R. J., J. E. Janowiak, P. A. Arkin, and P. Xie, 2004: CMORPH: A method that produces global precipitation estimates from passive microwave and infrared data at high spatial and temporal resolution. $J$. Hydromet., 5, 487-503.

[62] Beranger, K., B. Barnier, S. Gulev, and M. Crepon, 2006: Comparing 20 years of precipitation estimates from different sources over the world ocean. Ocean Dyn., 56, 104-138

[63] Stephens, G. L. and J. M. Haynes, 2007: Near global observations of the warm rain coalescence process. Geophys. Res. Lett., 34, L20805, doi:10.1029/2007GL030259.

[64] Stephens, G.L., and C.D. Kummerow, 2007: The remote sensing of clouds and precipitation from space: A review. J. Atmos. Sci., 64, 3742-3765.

[65] Bowman, K.P. 2005: Comparison of TRMM precipitation retrievals with rain gauge data from ocean buoys. $J$. Climate, 18, 178-190.

[66] Kalnay, E., et al., 1996: The NMC/NCAR 40-year Reanalysis Project. Bull.Amer.Meteor.Soc., 77,437471.

[67] Kanamitsu, M, W. Ebisuzaki, J. Woollen, S-K Yang, J .J. Hnilo, M. Fiorino, and G. L. Potter, 2002: NCEPDOE AMIP-II Reanalysis (R-2),. Bull. Amer. Met. Soc., 83, 1631-1643.

[68] Onogi, K., and coauthors, 2007: The JRA-25 reanalysis. J. Meteor. Soc. Japan, 85, 369-432.

[69] Uppala, S. M., and co-authors, 2005: The ERA-40 reanalysis. Quart. J. Roy. Meteor. Soc., 131, 29613012. 
[70] Xie, P., W. Wang, J.E. Janowiak, M. Chen, C.L. Shie, and L. Chiu, 2008: Examining fresh water flux over global oceans in the NCEP CDAS, CDAS2, GDAS, GFS and CFS. Third WCRP Intl Conf Reanalysis. Tokyo, Japan, Jan. 28 - Feb.1, 2008.

[71] Quartly, G.D., E.A. Kyte, M.A. Srokosz and M.N. Tsimplis, 2007, An intercomparison of global oceanic precipitation climatologies, J. Geophys. Res. 112, art. no. D10121, (18pp), doi:10.1029/2006JD007810.

[72] Kyte, E.A., G.D. Quartly, M.A. Srokosz and M.N. Tsimplis, 2006, Interannual variations in precipitation: The effect of the North Atlantic and Southern Oscillations as seen in a satellite precipitation data set and in models, J. Geophys. Res., 111, art. no. D24113. doi:10.1029/2006JD007138.

[73] Moore, G.W.K., and I.A. Renfrew, 2002: An Assessment of the Surface Turbulent Heat Fluxes from the NCEPNCAR Reanalysis over the Western Boundary Currents. J. Climate, 15, 2020-2037.

[74] Josey, S. A., 2001: A Comparison of ECMWF, NCEP/NCAR and SOC Surface Heat Fluxes with Moored Buoy Measurements In The Subduction Region of the North-East Atlantic. Journal of Climate, 14(8), 1780-1789.

[75] Rouault, M., C.J.C. Reason, J.R.E. Lutjeharms, and A.C.M. Beljaars, 2003: Underestimation of Latent and Sensible Heat Fluxes above the Agulhas Current in NCEP and ECMWF Analyses. J. Climate, 16, 776782 .

[76] Jiang, C., Cronin, M.F., Kelly, K.A., Thompson, L., 2005: Evaluation of a hybrid satellite- and NWP-based turbulent heat flux product using the Tropical Atmosphere-Ocean (TAO) buoys. J. Geophys. Res., 110, C09007, DOI:10.1029/2004JC002824.

[77] Yu, L., and R.A. Weller, 2007: Objectively analyzed airsea flux fields for the global ice-free oceans (19812005). Bull. Amer. Met. Soc., 88, 527-539.

[78] Large, W., Yeager, S., 2009: The global climatology of an interannually varying air-sea flux data set. Clim. Dynamics, DOI:10.1007/s00382-008-0441-3.

[79] Yu, L., R. A. Weller, and B. Sun, 2004a: Improving latent and sensible heat flux estimates for the Atlantic Ocean (1988-1999) by a synthesis approach. J. Clim., 17, 373-393.

[80] Yu., L., R.A. Weller, and B. Sun, 2004b: Mean and variability of the WHOI daily latent and sensible heat fluxes at in situ flux measurement sites in the Atlantic Ocean. J. Clim., 17, 2096-2118.

[81] Large W., 2006: Surface fluxes for practitioners of global ocean data assimilation. E. P. Chassignet and J. Verron (eds.), Ocean Weather Forecasting, 229-270. Springer. Printed in the Netherlands.

[82] Griffies, S. M., Biastoch, A., Boning, C., Bryan, F., Chassignet, E., England, M., Gerdes, R., Hallberg, R. W., Hazeleger, W., Large, B., Samuels, B. L., Scheinert, M., Schweckendiek, U., Severijns, C. A., Treguier, A. M., Winton, M., and Yeager, S.: A
Proposal for Coordinated Ocean-ice Reference Experiments (COREs), in prep, 2007.

[83] Roeske, F., 2006. A global heat and freshwater forcing dataset for ocean models. Ocean Modelling 11, 235297.

[84] Barnier B., and the DRAKKAR Group, 2007: Eddypermitting ocean circulation hindcasts of the last decades. Clivar Exchanges, 12, No.3.

[85] Brodeau, L., B., Barnier, A.-M. Treguier, T. Peduff, and S. Gulev, 2009: An ERA40-based atmospheric forcing for global ocean circulation models. Ocean Modelling (submitted).

[86] Trenberth, K. E., J. M. Caron, and D. P. Stepaniak, 2001: The atmospheric energy budget and implications for surface fluxes and ocean heat transports. Climate Dyn., $17,259-276$.

[87] Dong, S., S. T. Gille, and J. Sprintall, 2007: An assessment of the Southern Ocean mixed-layer heat budget, J. Clim., 20, 4425-4442.

[88] Hadfield, R. E., N. C. Wells, S. A. Josey and J. J-M. Hirschi, 2007: On the accuracy of North Atlantic temperature and heat storage fields from Argo, $J$. Geophys. Res., 112, C01009, doi:10.1029/2006JC003825.

[89] Stammer, D., K. Ueyoshi, A. Köhl, W.B. Large, S. Josey, and C. Wunsch, 2004: Estimating air-sea fluxes of heat, freshwater and momentum through global ocean data assimilation. J. Geophys. Res., 109, C05023, doi:10.1029/2003JC002082.

[90] Stammer, D. \& Co-Authors (2010). "Ocean Information Provided Through Ensemble Ocean Syntheses" in these proceedings (Vol. 2), doi:10.5270/OceanObs09.cwp.85.

[91] Skachko S., J.-M. Brankart, F. Castruccio, P. Brasseur, and J. Verron, 2009: Improved turbulent air-sea flux bulk parameters for the control of the ocean mixed layer: A sequential data assimilation approach. $J$. Atmos. Oceanic Tech., 26, 538-555.

[92] Carton, J.A., and B.S. Giese, 2008: A reanalysis of ocean climate using Simple Ocean Data Assimilation (SODA). Mon. Wea. Rev., 136, 2999-3017.

[93] Mazloff, M., P. Heimbach, and C. Wunsch, 2009: An eddy permitting Southern Ocean state estimate, Journal of Physical Oceanography, May 2010 (Vol. 40, No. 5, doi:10.1175/2009JPO4236.1

[94] Monteiro, P. \& Co-Authors (2010). "A Global Sea Surface Carbon Observing System: Assessment of Changing Sea Surface CO2 and Air-Sea CO2 Fluxes" in these proceedings ( Vol. 2), doi:10.5270/OceanObs09.cwp.64.

[95] Cooper, D. J., Watson, A. J., and Ling, R. D.: Variation of $\mathrm{pCO}_{2}$ along a North Atlantic shipping route (U.K. to the Caribbean): A year of automated observations, Marine Chemistry, 60, 147-164, 1998.

[96] Boutin, J. Merlivat, L. Hénocq, C. Martin, N. and Sallée J. B. Air-sea CO2 flux variability in frontal regions of 
the Southern Ocean from CARbon Interface OCean Atmosphere drifters Limnol. Oceanogr., 53(5, part 2), 2008, 2062-2079.

[97] Wanninkhof, R., W.E. Asher, D.T. Ho, C. Sweeney, and W.R. McGillis, 2009: Advances in quantifying air-sea gas exchange and environmental forcing. Annu. Rev. Mar. Sci., 1, 213-44

[98] O'Dowd, C.D., G. de Leeuw, 2007: Marine aerosol production: A review of the current knowledge. Phil. Trans. R. Soc. A 365, 1753-1774.

[99] Broecker, W.S., T.-H. Peng, G. Ostlund, and M. Stuiver, 1985: The distribution of bomb radiocarbon in the ocean. J. Geophys. Res., 99, 6953-6970.

[100] Broecker, W.S., S. Sutherland, W. Smethie, T.-H. Peng, and G. Ostlund, 1995: Oceanic radiocarbon: separation of the natural and bomb components. Glob. Biogeochem. Cycles, 9, 263-88.

[101] Sweeney, C., E. Gloor, A.R. Jacobson, R.M. Key, and G. McKinley G, et al., 2007: Constraining global airsea gas exchange for $\mathrm{CO} 2$ with recent bomb $14 \mathrm{C}$ measurements. Glob. Biogeochem. Cycles, 21, GB2015.

[102] Ho, D.T., C.S Law, M.J. Smith, P. Schlosser, M. Harvey, and P. Hill, 2006: Measurements of air-sea gas exchange at high wind speeds in the Southern Ocean: implications for global parameterizations. Geophys. Res. Lett., 33, L16611.

[103] Takahashi, T., Sutherland, S. C., Wanninkhof, R., Sweeney, C., Feely, R. A., Chipman, D. W., Hales, B., Friederich, G., Chavez, F., Watson, A. J., Bakker, D. C., Schuster, U., Metzl, N., and Yoshikawa-Inoue, H.: Climatological mean and decadal change in surface ocean $\mathrm{pCO}_{2}$, and net sea-air $\mathrm{CO}_{2}$ flux over the global oceans, Deep-Sea Res. II, in press, 2009.

[104] Takahashi, T., Sutherland, S. C., Sweeney, C., Poisson, A., Metzl, N., Tilbrook, B., Bates, N., Wanninkhof, R., Feely, R. A., Sabine, C., Olafsson, J., and Nojiri, Y.: Global sea-air $\mathrm{CO}_{2}$ flux based on climatological surface ocean $\mathrm{pCO}_{2}$, and seasonal biological and temperature effects, Deep-Sea Res. II, 49, 1601-1622, 2002.

[105] Lenton, A., Bopp, L., and Matear, R. J.: Strategies for high-latitude northern hemisphere $\mathrm{CO}_{2}$ sampling now and in the future, Deep-Sea Res. II, doi:10.1016/j.dsr2.2008.12.008, 2009.

[106] Schuster, U., and Watson, A. J. W.: A variable and decreasing sink for atmospheric $\mathrm{CO}_{2}$ in the North Atlantic, Journal of Geophysical Research, 112, doi:10.1029/2006JC003941, 2007.

[107] Corbière, A., Metzl, N., Reverdin, G., Brunet, C., and Takahashi, T.: Interannual and decadal variability of the oceanic carbon sink in the North Atlantic subpolar gyre, Tellus, 59B, 168-178, 2007.

[108] Lefevre, N., Watson, A. J., Olsen, A., Ríos, A. F., Pérez, F. F., and Johannessen, T.: A decrease in the sink for atmospheric $\mathrm{CO}_{2}$ in the North Atlantic, Geophysical Research Letters, 31, L07306,
doi:10.1029/2003GL018957, 2004.

[109] Lüger, H., Wanninkhof, R., Wallace, D. W. R., and Körtzinger, A., $\mathrm{CO}_{2}$ fluxes in the subtropical and subarctic North Atlantic based on measurements from a volunteer observing ship, Journal of Geophysical Research, 111, C06024, doi:10.1029/2005JC003101, 2006.

[110] Feely, R. A., Boutin, J., Cosca, C.E., Dandonneau, Y., Etcheto, J., Inoue, H., Ishii, M., LeQuere, C., Mackey, D.J., McPhaden, M., Metzl, N., Poisson, A., Wanninkhof, R., 2002. Seasonal and interannual variability of CO2 in the equatorial Pacific. Deep-Sea Res.II 49,2443-2469.

[111] Ishii, M., et al., Spatial variability and decadal trend of the oceanic $\mathrm{CO} 2$ in the western equatorial Pacific warm / freshwater. Deep-Sea Research II (2009), doi:10.1016/j.dsr2.2009.01.002

[112] Metzl, N., 2009. Decadal increase of oceanic carbon dioxide in the Southern Indian Ocean surface waters (1991-2007). Deep-Sea Research II, doi:10.1016/j.dsr2.2008.12.007

[113] Chierici, M., Olsen, A., Johannessen, T., Trinanes, J., and Wanninkhof, R.: Algorithms to estiamte the carbon dioxide uptake in the northern North Atlantic using shipboard observations, satellite and ocean analysis data, Deep Sea Research II, doi:10.1016/j.dsr2.2008.12.014 2009

[114] Telszewski, M., Chazottes, A., Schuster, U., Watson, A. J., Moulin, C., Bakker, D. C. E., Gonzalez-Davila, M., Johannessen, T., Kortzinger, A., Luger, H., Olsen, A., Omar, A., Padin, X. A., Rios, A., Steinhoff, T., Santana-Casiano, M., Wallace, D. W. R., and Wanninkhof, R.: Estimating the monthly $\mathrm{pCO}_{2}$ distribution in the North Atlantic using a selforganizing neural network, Biogeosci. Disc., 6, 3373 $3414,2009$.

[115] Stramski, D., R.A. Reynolds, M. Kahru and B.G. Mitchell. 1999. Estimation of particulate organic carbon in the ocean from satellite remote sensing. Science 285: 239-242.

[116] Behrenfeld, M.J., E. Boss, D.A. Siegel and D.M. Shea. Carbon-based productivity and phytoplankton physiology from space. Global Biogeochemical. Cycles, 19, GB1006, doi:10.1029/2004GB002299. 2005.

[117] Siegel, D.A., S. Maritorena, N.B. Nelson and M.J. Behrenfeld, 2005: Independence and interdependencies of global ocean color properties; Reassessing the bio-optical assumption. Journal of Geophysical Research, 110, C07011, doi:10.1029/2004JC002527

[118] Doney, S. C., Tilbrook, B., Roy, S., Metzl, N., Le Quéré, C., Hood, M., Feely, R. A., and Bakker, D.: Surface-ocean $\mathrm{CO}_{2}$ variability and vulnerability, Deep Sea Research II, doi:10.1016/J.dsr2.2008.12.016, 2009a. 
[119] Thomas, H., Prowe, A. E. F., Lima, I. D., Doney, S. C., Wanninkhof, R., Greatbatch, R. J., Schuster, U., and Corbiere, A.: Changes in the North Atlantic Oscillation influence $\mathrm{CO}_{2}$ uptake in the North Atlantic over the past 2 decades, Global Biogeochem. Cycl., 22, doi:10.1029/2007GB003167, 2008.

[120] Breivik, L. \& Co-Authors (2010). "Remote Sensing of Sea Ice" in these proceedings (Vol. 2), doi:10.5270/OceanObs09.cwp.11.

[121] Steffen, K., Schweiger, A.J. 1991. NASA Team Algorithm for Sea Ice Concentration Retrieval from Defense Meteorological Satellite Program Special Sensor Microwave Imager: Comparison with Landsat Satellite Imagery. Journal of Geophysical Research, Vol. 96, no. C12, 21,971 - 21,987

[122] Kwok, R., G. F. Cunningham, H. J. Zwally, and D. Yi, 2007, Ice, Cloud, and land Elevation Satellite (ICESat) over Arctic sea ice: Retrieval of freeboard, $J$. Geophys. Res., 112, C12013

[123] Kwok, R., and G. F. Cunningham, 2008, ICESat over Arctic sea ice: Estimation of snow depth and ice thickness, J. Geophys. Res., 113, C08010

[124] Farrell, S. L., S. W. Laxon, D. C. McAdoo, D. Yi, and H. J. Zwally (2009), Five years of Arctic sea ice freeboard measurements from the Ice, Cloud and land Elevation Satellite, J. Geophys. Res., 114, C04008, doi:10.1029/2008JC005074.

[125] Martin, T., and E. Augstein, 2000: Large-scale drift of Arctic sea ice retrieved from passive microwave satellite data. J. Geophys. Res., vol. 105 (C4), 87758788 .

[126] Girard-Ardhuin F., R. Ezraty, and D. Croizé-Fillon, 2008: Arctic and Antarctic sea ice concentration and sea ice drift satellite products at Ifremer/CERSAT. Mercator-Ocean Quarterly newsletter, January 2008.

[127] Fowler, C. 2003, updated 2007. Polar Pathfinder Daily $25 \mathrm{~km}$ EASE-Grid Sea Ice Motion Vectors, [list the dates of the data used]. Boulder, Colorado USA: National Snow and Ice Data Center. Digital media.

[128] Zhang, J., D. R. Thomas, D. A. Rothrock, R. W. Lindsay, and Y. Yu, 2003: Assimilation of ice motion observations and comparisons with submarine ice thickness data. J. Geophys. Res., vol. 108 (C6), 3170, doi:10.1029/2001JC001041.

[129] Stark, J., and A. Hines, 2008: Sea ice concentration and drift data assimilation in the UK. Mercator-Ocean Quarterly newsletter, January 2008.

[130] Norris, S.J., I.M. Brooks, G. de Leeuw, M.H. Smith, M. Moerman, and J.J.N. Lingard, 2008: Eddy covariance measurements of sea spray particles over the Atlantic Ocean. Atmos. Chem. Phys., 8, 555-563.

[131]Ma, B.B. and J.A. Nystuen, 2005: Passive Acoustic Detection and Measurement of Rainfall at Sea, $J$. Atmos. and Oceanic Tech. 22 1225-1248.

[132] McGillis, W., J.B. Edson, J.D. Ware, J.W.H. Dacey, J.E. Hare, C.W. Fairall, R. Wanninkhof, 2001: Carbon dioxide flux techniques performed during GasEx-98. W.R. Journal of Marine Chemistry, 75, 267-280.

[133] Byrne, R. \& Co-Authors (2010). "Sensors and Systems for In Situ Observations of Marine Carbon Dioxide System Variables" in these proceedings (Vol. 2), doi:10.5270/OceanObs09.cwp.13.

[134] Compo, G.P., and co-authors, 2009: The Twentieth Century Reanalysis Project. Bull. Amer. Met. Soc., in preparation.

[135] Cronin, M. \& Co-Authors (2010). "Monitoring Ocean Atmosphere Interactions in Western Boundary Current Extensions" in these proceedings (Vol. 2), doi:10.5270/OceanObs09.cwp.20.

[136] Josey, S. A. and S. R. Smith, 2006: Guidelines for Evaluation of Air-Sea Heat, Freshwater and Momentum Flux Datasets, CLIVAR Global Synthesis and Observations Panel (GSOP) White Paper, July 2006, pp. 14. Available at: http://www.clivar.org/organization/gsop/docs/gsopfg.p $\underline{\mathrm{df}}$ 